\title{
Diversification of Description Forms of English Version of Bachelor's Degrees in Japan: Current State by Academic Fields and Types of Universities as found by 2017 Survey
}

\author{
Nozomi Takahashi *, Rie Mori ${ }^{\dagger}$
}

\begin{abstract}
Although it has been a great concern regarding the excessive diversification of nomenclatures of academic fields of academic degrees and description forms of English version of them, little study has been conducted to address factors associated with the diversification. This study aims to examine the current state of the diversification of description forms of English version of bachelor's degrees based on the results of the National Survey that National Institution for Academic Degrees and Quality Enhancement of Higher Education (NAID-QE) implemented in 2017. Analyses of 723 universities' responses (response rate $=96.7 \%$ ) revealed that description forms of English version of bachelor's degrees shows different tendencies in each academic field and type of university. In addition, the uniformity of the form of description within a university was detected: it indicates that forms employed by newer universities show more variation compared to those of traditional universities. These results suggest that the diversification of English version of bachelor's degrees might be associated with both factors of academic fields and types of universities such as types and years of establishment, size of student bodies, and specific traits. It is hoped that the findings of this study help the development of policies for better international recognition of qualifications related to quality assurance on Japanese higher education.
\end{abstract}

Keywords: international recognition of qualifications, quality assurance, description forms of English version of bachelor's degree, nomenclatures of academic fields of academic degrees.

\section{Introduction}

\subsection{Diversification of description forms of English version of bachelor's degree in Japan}

It has been often discussed that excessive diversification of nomenclature of academic fields

* University of the Ryukyus, Okinawa, Japan

$\uparrow$ National Institution for Academic Degrees and Quality Enhancement of Higher Education, Tokyo, Japan 
appearing in diplomas and diversification of description forms of English version of them might disrupt the international recognition of qualifications issued by Japanese higher education institutions. This study focuses on the latter diversification and aims to examine the current status of it by academic fields and types of universities. These diversifications started to occur with the deregulation of Standards for the Establishment of Universities in 1991. Before 1991, the nomenclature of all three kinds of academic degrees the bachelor's, master's and doctoral - had been prescribed in the Standards. In the case of bachelor's degree, for example, previously 29 kinds of nomenclature that named individual majors, such as Bachelor of Literature or Bachelor of Engineering, had been prescribed. After deregulation, only "Bachelor, Master and Doctor" remained in the Standards: Universities can now choose nomenclatures of major academic fields that appear in parentheses that follow each title showing the focal area of study that a student has performed. Thus, the title that appears on diplomas was changed from, for example, Bachelor of Literature to Bachelor (Literature). Because of this, the variety of nomenclatures of major disciplines employed by Japanese universities started to expand rapidly after 1991, then reached over 700 kinds of nomenclature as found by 2015 National Survey [1]. According to a study that examines the variety of the nomenclatures of major disciplines used nationwide, approximately $60 \%$ of those nomenclatures are used by single universities [1][2][3].

As noted above, as a consequence of the deregulation, Japanese version of academic degrees were described in the rule like Bachelor (Literature), whereas those of English version was described without a rule and then diversified. For example, at "Guidance on preparation of documents to be submitted for establishment of universities" published by Ministry of Education, Culture, Sports, Science and Technology (MEXT) [4], it is instructed to fill in the fields of academic degree and nomenclature of academic fields according to an example "Bachelor (Law)" in the "Entry example" of the document that outlines the newly established curriculum. According to a study that examines the variety of description forms of English version of bachelor's degree used nationwide, there are mainly five types of form of description (see Table 1 for details) and is a tendency to express each field of discipline directly (Direct Express of Discipline type, hereafter): Bachelor of Literature, Bachelor of Engineering or Bachelor of Medicine, whereas structural description, such as Bachelor of Arts in [major] or Bachelor of Science in [major] (U.K./U.S. type with Concentration, hereafter) is not widely used as found 2004 National Survey [2].

These phenomena especially attracted criticism (c.f., [5]) as extreme variety of majors and ununiformed description forms of English version may disturb the ability of credentials in stating students' academic attainments especially in international environments. Most notably, the Science Council of Japan Committee attempted to establish a certain rule for the nomenclature of academic fields in academic degrees in order to secure them to be relevant to academic trends and coherent to international recognition [6]. In the report, the critics encouraged universities to present structural description in English version of bachelor's degrees as U.K./U.S. type with Concentration such as Bachelor of Arts in [major] or Bachelor of Science in [major], which has been used in U.K. and U.S. [6]. However, they also noted that a particular academic field or educational program developing highly professional or wide-ranging human resources, direct description of academic fields such as Bachelor of Law, Bachelor of Medicine or Bachelor of Engineering is applicable. Critics emphasized that, due to the lack of common sense of description form of English version of academic degree all over the world, it is important to have a rule for an agreed style of description of academic degrees, and to disseminate it to the world. 


\subsection{Literature review for forms of English version of bachelor's degree}

In order to examine the current status of diversification of description form of English version of bachelor's degree, previous studies that examine factor of extreme variety of majors of bachelor's degree course and differences of description forms of English version between bachelor's, master's and doctoral degree courses were reviewed [1][2]. The level of diversification of nomenclature of academic fields differs by academic fields and types of universities such as categories and years of establishment, size of student bodies, and specific traits [2]. That suggests that the nomenclature of bachelor's degree may vary by the level of social appreciation of disciplines in each academic field and the possible appeal of future qualification to prospective students. That also suggests that university attributes, such as selectivity or prestige defined by their research achievements, may have influenced the diversification of the nomenclature of bachelor's degree. It is presumable that these factors of academic fields and types of universities would contribute to the diversification of forms of description of English version of bachelor's degrees too.

Analyses the data from 2015 National Survey showed that at bachelor's and master's degree programs, there is a tendency to use Direct Express of Discipline type: Bachelor of Literature, Bachelor of Engineering or Bachelor of Medicine, whereas structural terminology that we call U.K./U.S. type with Concentration, such as Bachelor of Arts in [major] or Bachelor of Science in [major], is not widely used (at bachelor's level see Table 3 for details) [1]. On the other hand, the majority of doctoral degrees were presented using cohesive grouping of disciplines such as Doctor of Philosophy in [major] or Ph.D. in [major]. The results for bachelor' degree courses indicate a similar tendency from the results of 2004 survey [2], suggesting the effect of administrative efforts by critics are not significant at the level over the decades.

\subsection{Purpose of this study and research question}

There has been a considerable discussion regarding the excessive diversification of English version of bachelor's degrees as seen above and administrative efforts have been made to reduce the variation with little impact. However, little study has been conducted to address factors associated with the diversification. Recently, the Asia-Pacific Regional Convention on the Recognition of Qualifications in Higher Education known as the Tokyo Convention which aimed to help facilitating the recognition of higher education qualifications based on common principles, increased information sharing and transparency came into force on 1 February 2018. Therefore, the flow of qualification approval at the government level may accelerate and then, cross-border mobility in Asia-Pacific higher education may be major boosted in the future.

Based on awareness of these problems, this study aims to examine the current state, especially factors to contribute to the diversification of English version of bachelor's degrees. Specifically, we examine three research questions; (1) if there is a distinct trend in forms of description employed in English version of bachelor's degrees (2) whether factors of academic fields and types of universities contribute to the diversification of forms of description of English version of bachelor's degrees, hypothesizing that both academic field and type of university such as types and years of establishment, size of student bodies and specific traits contribute to the diversification of English version of bachelor's degrees, (3) to what extent universities has an uniformity of the form of description within a university, hypothesizing that types of universities such as types and years of establishment, size of student bodies and specific traits contribute to have variation of forms in a university. This study attempts to develop accumulated research and 
provide information for the development of policies for better international recognition of qualifications.

\section{Method}

\subsection{Summary of the National Survey in $\mathbf{2 0 1 7}$}

The National Survey was conducted by National Institution for Academic Degrees and Quality Enhancement of Higher Education (NIAD-QE) in 2017. A total of 723 universities (82 national, 81 public and 560 private universities) responded. The response rate was $96.7 \%$. The online questionnaire requires to list all nomenclatures of academic fields and English version of degrees awarded by the university. Universities and departments that have stopped accepting students were asked to complete the questionnaire until final cohort of students complete the typical duration of study. All nomenclatures of academic fields were classified and counted based on their academic discipline according to eleven academic discipline codes used in School Basic Survey of MEXT (see Figure 1 for details) [7].

\subsection{Data analysis}

\subsubsection{Data classification}

Following [2], English version of bachelor's degrees were classified into five categories namely U.K./U.S. type, U.K./U.S. type with Concentration, Direct Express of Discipline type, Literal Translate type and Professional Degree type according to the definition of description forms (Table 1). Following [1][2], Bachelor of Arts or Bachelor of Science were classified as U.K./U.S. type; Bachelor of Arts in [major] or Bachelor of Science in [major] was classified as U.K./U.S. type with Concentration. It is noted that in cases where the nomenclature in Japanese is as Bachelor (Science) and the English version is its direct translation: Bachelor of Science, they are classified not as U.K./U.S. type but Direct Express of Discipline type because it is assumed that, in universities in Japan, Bachelor (Science) can be translated to Bachelor of Science based on the idea to directly express narrower discipline of Science as specific professional field, not as is widely accepted in U.K. or U.S. where Science major is taken for wider variety of scholarship that corresponds to Arts [1]. That is the same as the idea which particular academic field or educational program developing highly professional or wide-ranging human resources directly express discipline such as Bachelor of Engineering in U.K. or U.S.

As for the classification of universities in types, we classified private universities following the definitions employed in [8][9] (Table 2). 560 responded private universities were, then, classified as follows: 1st Generation Core; 10 universities, 1st Generation Peripheral; 56 universities, 1st Generation Niche; 61 universities, 2nd Generation; 154 universities, 3rd Generation; 132 universities and 4th Generation; 147 universities.

\subsubsection{Data calculation and statistics}

Regarding the research question 2, chi-square analysis was employed to examine whether the factor of academic fields and types of universities contribute to the diversification of forms of description of English version of bachelor's degrees separately. Post hoc, a residual analysis was used to identify those specific cells making the greatest contribution to the chi-square test result. It is noted that, according to [10], if more than $20 \%$ of the expected counts are less than 5 and 
individual expected counts are 0 , the case will not have a chi-square distribution and, accordingly, result of the test ( $p$-value) will not be valid. Therefor such cases are excluded from data analysis in this study. An adjusted residual that is more than 1.96 indicates that the number of cases in that cell is significantly larger than what would be expected, whereas those of that is less than -1.96 indicates that the number of cases in that cell is significantly smaller.

As for the research question 3, we calculated out the variation index and used it as indicator to measure the extent of the uniformity of the form of description within a university. The variation index is calculated out by dividing the number of variations of the forms (maximum=5) that each university employs by number of degree programs that the university has. The range of the index is 1 to 0 . It is suggested that the closer to 1 the index is, the lower the uniformity of the form of description within a university is defined.

To examine the research question 3, one-way analysis of variance (ANOVA) was employed to examine the extent of the uniformity of the form of description within a university. Post hoc a Tukey's HSD (honestly significant difference test) was used to identify differences among sample means for significance.

The statistical analyses were conducted with IBM SPSS Statistics version 24.0 (IBM, Chicago, IL).

Table 1: Categories of description forms of English version of bachelor's degrees

\section{Definition from [1][2]}

\begin{tabular}{|l|l|}
\hline \multicolumn{1}{|c|}{ Category } & \multicolumn{1}{c|}{ Definition of Description Form } \\
\hline U.K./U.S. type & $\begin{array}{l}\text { Bachelor of Arts (B.A.), Bachelor of Science } \\
\text { (B.S.) except Bachelor (Science) in Japanese }\end{array}$ \\
\hline U.K./U.S. type with Concentration & $\begin{array}{l}\text { Bachelor of Arts (B.A.) in [major], Bachelor } \\
\text { of Science (B.S.) in [major] }\end{array}$ \\
\hline Direct Express of Discipline type & Bachelor of [major] \\
\hline Literal Translate type & Bachelor ([major]), Bachelor in [major] \\
\hline Professional Degree type & e.g., Doctor of Medicine (M.D.) \\
\hline
\end{tabular}

Table 2: Classification of private university

Definition from [8][9]

\begin{tabular}{|l|l|}
\hline \multicolumn{1}{|c|}{ Category } & \multicolumn{1}{c|}{ Definition } \\
\hline 1st Generation Core & $\begin{array}{l}\text { Mass universities played a core role in private univer- } \\
\text { sities and established through 1959. }\end{array}$ \\
\hline 1st Generation Peripheral & $\begin{array}{l}\text { Middle-sized or larger universities that enlarged uni- } \\
\text { versity admission quota in a period of higher education } \\
\text { expansion and established through 1959. }\end{array}$ \\
\hline 1st Generation Niche & $\begin{array}{l}\text { Small universities corresponded to special academic } \\
\text { demands such as female education, medicine, dentistry, } \\
\text { pharmacy, theology, art, and established through 1959. }\end{array}$ \\
\hline 2nd Generation & Universities established from 1960 through 1974. \\
\hline 3rd Generation & Universities established from 1975 through 1997. \\
\hline 4th Generation & Universities established from 1998 to present. \\
\hline
\end{tabular}




\section{Results}

\subsection{Research question 1: Transition of diversification of English version of bach- elor's degrees}

The number of degree programs and ratio in each form of description at 2017 and 2015 [1] is shown in Table 3. It shows that, both 2017 and 2015 results, the majority of Bachelor's degrees conferred in Japan express the field of discipline directly, whereas structural description, such as Bachelor of Arts, Bachelor of Science, Bachelor of Arts in [major] or Bachelor of Science in [major], is not widely used by Japanese universities. It is noted that Literal Translate type and Professional Degree type are used at approximately $1 \%$ of degree programs. To summarize these results, there is no visible difference of tendency of description forms between the results of 2017 and 2015, suggesting administrative efforts to reduce the variation in styles of degree-description at the national level has made little impact to actual policy and practice at the institutional level.

Table 3: Number of degree programs and ratio in each form of description

Data of 2015 from [1]

\begin{tabular}{lrrrrr}
\hline \multicolumn{1}{c}{ Category } & \multicolumn{2}{c}{$\begin{array}{l}\text { Number of } \\
\text { degree programs }\end{array}$} & \multicolumn{2}{c}{ ratio $(\%)$} \\
& 2017 & 2015 & 2017 & 2015 \\
U.K./U.S. type & 495 & 534 & 8.19 & 8.81 \\
U.K./U.S. type with Concentration & 1110 & 1113 & 18.36 & 18.37 \\
Direct Express of Discipline type & 4321 & 4279 & 71.47 & 70.63 \\
Literal Translate type & 61 & 74 & 1.01 & 1.22 \\
Professional Degree type & 59 & 58 & 0.98 & 0.96 \\
Total & 6045 & 6058 & 100 & 100 \\
\hline
\end{tabular}

\subsection{Research question 2: Diversification of English version of bachelor's degrees by academic fields}

The ratio of forms used for description classified by different academic fields is shown in Figure 1. It shows that, in field of Science, Engineering and, Agriculture, there is a tendency to express the field of discipline directly, whereas structural description, such as Bachelor of Arts, Bachelor of Science, Bachelor of Arts in [major] or Bachelor of Science in [major], is relatively highly used in Humanities, Social Sciences, Home Economics and Art.

To explore whether there is a significant deference in the forms of description among academic fields, a chi-square test of independence was performed on the cross table of forms of description by academic fields (Table 4). Since more than $20 \%$ of the expected counts are less than 5, cells for Professional Degree type and Merchant Marine Science were excluded from the 
analysis. The analysis revealed a statistically significant difference among the academic fields $\left(\chi^{2}\right.$ $(27)=1942.74, p<0.01)$. To further analysis, to identify those specific cells making the greatest contribution to the chi-square test result, a residual analysis was performed. Adjusted standardized residuals and $p$-values are showed in Table 4.

In fields of Science, Engineering, Agriculture and Health Sciences, Direct Express of Discipline type is significantly highly used, whereas U.K./U.S. type and those of with Concentration are not significantly highly used. In the field of Humanities, on the other hand, U.K./U.S. type and those of with Concentration is significantly highly used, whereas Direct Express of Discipline type is not significantly highly used. In fields of Social Sciences and Other, U.K./U.S. type with Concentration is, and in the field of Art U.K./U.S. type is used significantly more often. In Social Sciences and Others, U.K./U.S. type with Concentration is used significantly more often. It is notable that Literal Translate type is significantly highly used in Education whereas those are rarely used in Engineering. The analysis indicates that employed forms of description vary in accordance with the academic field. The results suggest that, in each academic field, there is conformity of styles: professional academic fields such as Science, Engineering, Agriculture, Health Sciences tend to express their discipline directly, whereas transdisciplinary academic fields such as Humanities, Social Sciences, Art and Others tend to adapt the structural style that U.K. or U.S. universities employ.

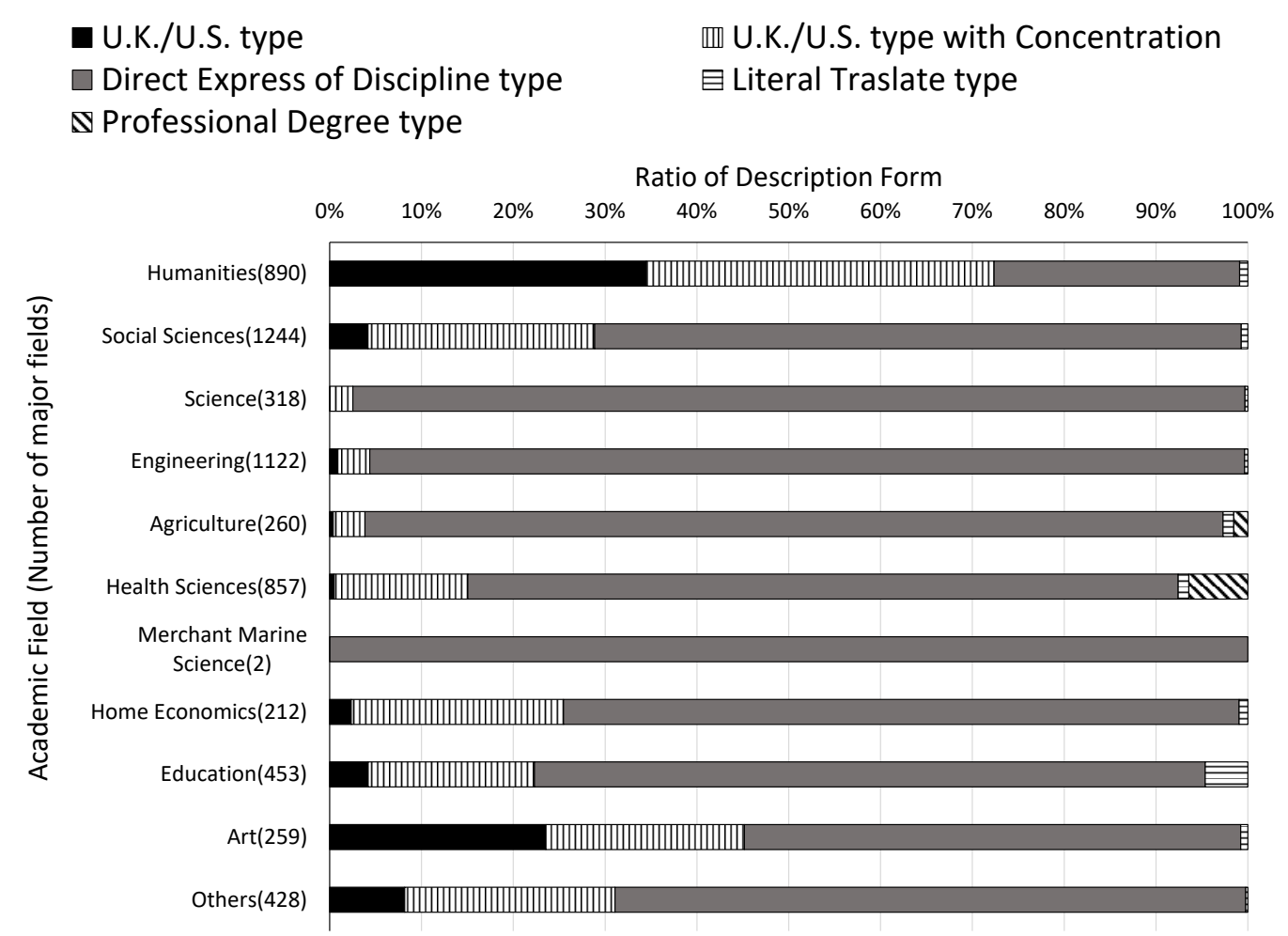

Figure 1: The distribution of forms of description by academic fields 
Table 4: Number of degree programs in each form of description by academic fields

\begin{tabular}{|c|c|c|c|c|c|}
\hline & \multicolumn{5}{|c|}{ Description forms of English Version } \\
\hline & $\begin{array}{l}\text { U.K./U.S. } \\
\text { type }\end{array}$ & $\begin{array}{c}\text { U.K./U.S. } \\
\text { type with } \\
\text { Concentration }\end{array}$ & $\begin{array}{c}\text { Direct } \\
\text { Express of } \\
\text { Discipline } \\
\text { type }\end{array}$ & $\begin{array}{l}\text { Literal } \\
\text { Translate } \\
\text { type }\end{array}$ & Total \\
\hline Humanities & $307(30.8 * *)$ & $337(16.1 * *)$ & $238\left(-32.8^{* *}\right)$ & $8(-0.4)$ & 882 \\
\hline Social Sciences & $52\left(-5.9^{* *}\right)$ & $307\left(6.2^{* *}\right)$ & $876(-1.8)$ & $9(-1.2)$ & 1235 \\
\hline Science & $0\left(-5.5^{* *}\right)$ & $8\left(-7.6^{* *}\right)$ & $309(10.1 * *)$ & $1(-1.3)$ & 317 \\
\hline Engineering & $10\left(-10.0^{* *}\right)$ & $39(-14.5 * *)$ & $1069\left(19.0^{* *}\right)$ & $4\left(-2.5^{*}\right)$ & 1118 \\
\hline Agriculture & $1(-4.7 * *)$ & $9(-6.3 * *)$ & $243\left(8.5^{* *}\right)$ & $3(0.2)$ & 253 \\
\hline Health Sciences & $4\left(-8.6^{* *}\right)$ & $125\left(-2.3^{*}\right)$ & $663\left(7.3^{* *}\right)$ & $10(0.7)$ & 792 \\
\hline Home Economics & $5(-3.2 * *)$ & $49(1.7)$ & $156(0.5)$ & $2(-0.1)$ & 210 \\
\hline Education & $19(-3.1 * *)$ & $82(0.1)$ & $331(1.8)$ & $21\left(8.0^{* *}\right)$ & 432 \\
\hline Art & $61(9.1 * *)$ & $56(1.3)$ & $140\left(-6.8^{* *}\right)$ & $2(0.4)$ & 257 \\
\hline Others & $35(-0.1)$ & $98\left(2.3^{*}\right)$ & $294(-2.0 *)$ & $1(-1.7)$ & 427 \\
\hline Total & 494 & 1110 & 4319 & 61 & 5984 \\
\hline
\end{tabular}

Note: () indicates adjusted standardized residuals. $* * p<.01, * p<.05$

\subsection{Research question 2: Diversification of English version of bachelor's degrees by types of universities}

Figure 2 shows the ratio of forms of description by types of universities. It is indicated that in addition to National and Public universities, 2nd, 3rd and 4th Generations of private universities tend to express each field of discipline directly, whereas structural description, such as Bachelor of Arts in [major] or Bachelor of Science in [major], is relatively highly used in 1st Generation Core, Peripheral and, Niche private universities.

To explore whether there is a significant deference by types of universities in distribution of forms of description, a chi-square test of independence was performed on the cross table of forms of description by types of universities (Table 5). Since more than $20 \%$ of the expected counts are less than 5, cells for Professional Degree type were excluded from the analysis. The analysis revealed a statistically significant difference among the types of universities $\left(\chi^{2}(21)=\right.$ $495.45, p<0.01)$. To further analysis, to identify those specific cells making the greatest contribution to the chi-square test result, a residual analysis was performed. Adjusted standardized residuals and $p$-values are showed in Table 5 .

At National universities, the usage of Direct Express of Discipline type is significantly high whereas those of U.K./U.S. type and those with Concentration is significantly low. The opposite 
pattern is found at 1st Generation Niche and 2nd Generation private universities; they mainly use U.K./U.S. type and those with Concentration whereas they rarely use Direct Express of Discipline type. Similar pattern was found at Public universities and 1st Generation Core and Peripheral universities in which they mainly used U.K./U.S. with Concentration whereas they rarely use Direct Express of Discipline type. At 1st Generation Peripheral and 4th Generation private universities, usage of Lateral Translate type is significantly high, whereas at 2nd and 3rd Generation universities show significantly low rate of usage of that type. It is notable that newer universities such as 3rd and 4th Generation private universities do not show any significance of usage both U.K./U.S. type with Concentration and Direct Express of Discipline type. The results suggest that within each type of university we can find certain conformity such as at National university tend to express their discipline directly, whereas Public universities and relatively traditional universities such as 1st Generation Core, Peripheral, Niche and 2nd Generation private universities tend to adapt the style that U.K. or U.S. universities employ.

U.K./U.S. type

$\square$ Direct Express of Discipline type

s Professional Degree type

\section{皿 U.K./U.S. type with Concentration \\ 目 Literal Traslate type}

Ratio of Description Form

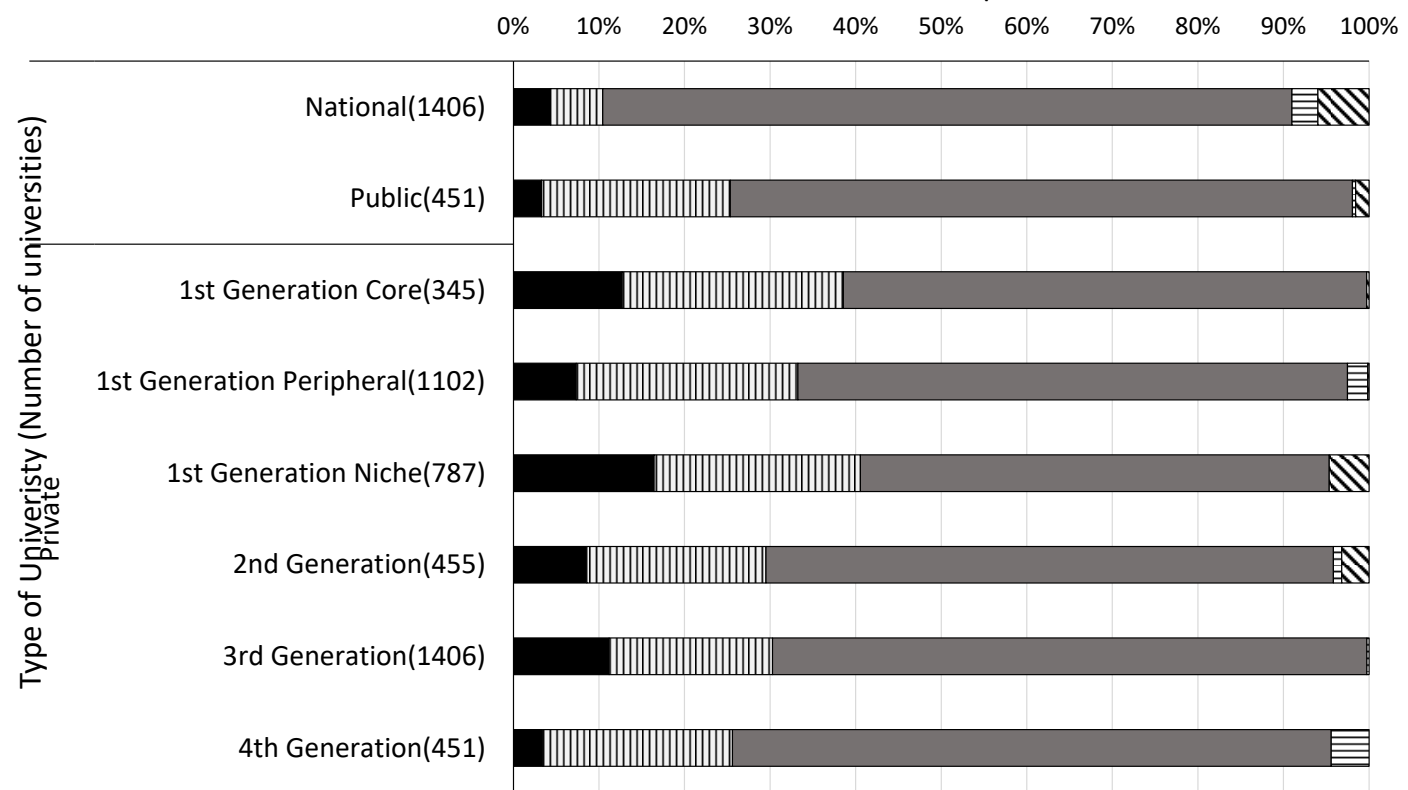

Figure 2: The distribution of forms of description by types of universities 
Table 5: Number of degree programs in each form of description by types of universities

\begin{tabular}{|c|c|c|c|c|c|}
\hline & \multicolumn{5}{|c|}{ Description forms of English Version } \\
\hline & $\begin{array}{l}\text { U.K./U.S. } \\
\text { type }\end{array}$ & $\begin{array}{l}\text { U.K./U.S. } \\
\text { type with } \\
\text { Concentration }\end{array}$ & $\begin{array}{c}\text { Direct } \\
\text { Express of } \\
\text { Discipline type }\end{array}$ & $\begin{array}{l}\text { Literal } \\
\text { Translate } \\
\text { type }\end{array}$ & Total \\
\hline National & $70\left(-4.8^{* *}\right)$ & $66(-14.9 * *)$ & $1226\left(16.2^{* *}\right)$ & $10(-1.2)$ & 1372 \\
\hline Public & $20(-3.0 * *)$ & $125\left(5.3^{* *}\right)$ & $298\left(-2.6^{* *}\right)$ & $4(-0.3)$ & 447 \\
\hline \multicolumn{6}{|l|}{ Private } \\
\hline $\begin{array}{l}\text { 1st Generation } \\
\text { Core }\end{array}$ & $36(1.6)$ & $110(6.7 * *)$ & $198\left(-6.0^{* *}\right)$ & $0(-1.9)$ & 344 \\
\hline $\begin{array}{l}\text { 1st Generation } \\
\text { Peripheral }\end{array}$ & 103 (1.6) & $238(3.1 * *)$ & $736(-3.8 * *)$ & $22\left(3.6^{* *}\right)$ & 1099 \\
\hline $\begin{array}{l}\text { 1st Generation } \\
\text { Niche }\end{array}$ & $68(7.8 * *)$ & $93(3.9 * *)$ & $189(-7.9 * *)$ & $0\left(-2.0^{*}\right)$ & 350 \\
\hline 2nd Generation & $110\left(2.0^{*}\right)$ & $247(3.1 * *)$ & $771(-3.3 * *)$ & $4\left(-2.5^{*}\right)$ & 1132 \\
\hline 3rd Generation & $76(1.6)$ & $142(-0.2)$ & $568(0.5)$ & $1(-2.7 * *)$ & 787 \\
\hline 4th Generation & $11(-4.7 * *)$ & $89(0.7)$ & $335(1.1)$ & $20\left(7.5^{* *}\right)$ & 455 \\
\hline Total & 494 & 1110 & 4321 & 61 & 5986 \\
\hline
\end{tabular}

\subsection{Research question 3: The uniformity of the form of description within a uni- versity}

Distribution of the variation index by types of universities is shown in Figure 3. Mean variation index of types of universities groups is $0.37(S D=0.32)$. In Figure 3, it is shown that newer universities tend to have more variation of forms, compared to traditional universities.

To explore whether the variation index of each type of university differs, we performed a one-way ANOVA on the variation index of types of universities. The analysis revealed a statistically significant difference among the types of universities, $F(7,715)=21.48, p<0.01$ (Table 6). Tukey's HSD test was used to determine the significant differences among the types of universities groups (Table 7). The newest 4th Generation private university group shows the highest mean variation index among the university groups (4th Generation vs National, $p<.01$; vs Public, $p<.05$, vs 1st Generation Core, $p<.01$; vs 1 st Generation Niche, $p<.01$; vs 1st Generation Peripheral, $p<.05$; vs 2 nd Generation, $p<.01$; vs 3rd Generation, $p<.01$ ). The mean variation index of second newest 3rd Generation private university group is higher than traditional National, Private 1st Generation Core and Niche universities (3rd Generation vs National, $p<.05$; vs 1st Generation Core, $p<.05$, vs 1 st Generation Niche, $p<.01$ ). The third newest 2nd Generation private university and Pubic university groups in which the majority of institutions were establish ed in 1960's or later, show relatively high variation index, compared to traditional universi- 
ties such as National and Private1st Generation Core or Peripheral university groups (2nd Generation vs 1st Generation Peripheral, $p<.01$; Pubic vs National, $p<.05$; vs 1st Generation Core, $p$ $<.05$, vs 1st Generation Peripheral, $p<.01$ ). Interestingly, even though 1st Generation Niche private university group was categorized as traditional, it shows a pattern similar to Public university group which shows higher variation index than traditional universities such as National and Private 1st Generation Core or Peripheral university groups (1st Generation Niche vs National, $p<.05$; vs 1st Generation Core, $p<.05$, vs 1st Generation Peripheral, $p<.01)$. The results suggest that newer universities tend to have more variation of forms, compared to traditional universities.

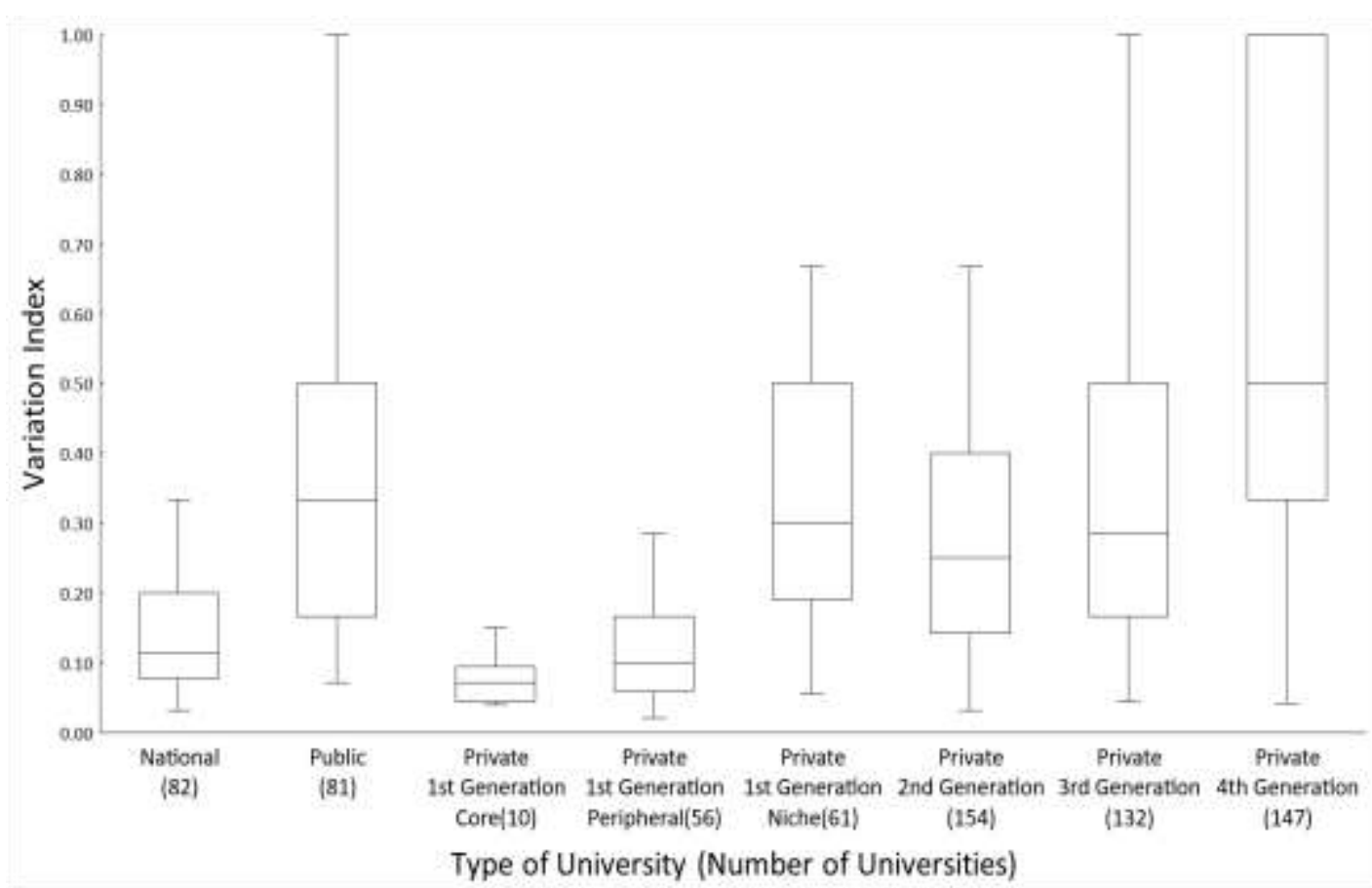

Figure 3: The distribution of variation index by types of universities

Table 6: One-way ANOVA on the variation index of types of universities

\begin{tabular}{lrrrrr}
\hline & Sum of square & $d f$ & Mean square & $F$ value & Sig, \\
& 12.52 & 7 & 1.79 & 21.48 & 0.001 \\
Between Group & 59.54 & 715 & 0.08 & & \\
Within Group & 72.06 & 722 & & & \\
Total & & & & & \\
\hline
\end{tabular}


Table 7: Mean difference (I-J) and Tukey's HSD tests comparisons among groups of university

\begin{tabular}{|c|c|c|c|c|c|c|c|c|c|}
\hline & & \multicolumn{8}{|c|}{ Group (J) } \\
\hline & & 1 & 2 & 3 & 4 & 5 & 6 & 7 & 8 \\
\hline 1 & National & - & $\begin{array}{l}-0.21 * \\
(0.05)\end{array}$ & $\begin{array}{r}0.16 \\
(0.1)\end{array}$ & $\begin{array}{r}0.12 \\
(0.06)\end{array}$ & $\begin{array}{r}-0.18^{*} \\
(0.05)\end{array}$ & $\begin{array}{r}-0.09 \\
(0.04)\end{array}$ & $\begin{array}{r}-0.14 * \\
(0.05)\end{array}$ & $\begin{array}{r}-0.34 * * \\
(0.04)\end{array}$ \\
\hline 2 & Public & & - & $\begin{array}{r}0.35^{*} \\
(0.1)\end{array}$ & $\begin{array}{r}0.31 * * \\
(0.06)\end{array}$ & $\begin{array}{r}0.02 \\
(0.05)\end{array}$ & $\begin{array}{r}0.11 \\
(0.04)\end{array}$ & $\begin{array}{r}0.06 \\
(0.05)\end{array}$ & $\begin{array}{r}-0.15^{*} \\
(0.04)\end{array}$ \\
\hline 3 & $\begin{array}{l}\text { 1st Generation } \\
\text { Core }\end{array}$ & & & - & $\begin{array}{r}-0.05 \\
(0.1)\end{array}$ & $\begin{array}{r}-0.34^{*} \\
(0.1)\end{array}$ & $\begin{array}{r}-0.25 \\
(0.1)\end{array}$ & $\begin{array}{r}-0.30^{*} \\
(0.1)\end{array}$ & $\begin{array}{r}-0.50 * * \\
(0.1)\end{array}$ \\
\hline 4 & $\begin{array}{l}\text { 1st Generation } \\
\text { Peripheral }\end{array}$ & & & & - & $\begin{array}{r}-0.30 * * \\
(0.06)\end{array}$ & $\begin{array}{r}-0.20 * * \\
(0.05)\end{array}$ & $\begin{array}{r}-0.26 * * \\
(0.05)\end{array}$ & $\begin{array}{r}-0.45^{* *} \\
(0.05)\end{array}$ \\
\hline 5 & $\begin{array}{l}\text { 1st Generation } \\
\text { Niche }\end{array}$ & & & & & - & $\begin{array}{r}0.10 \\
(0.05)\end{array}$ & $\begin{array}{r}0.04 \\
(0.05)\end{array}$ & $\begin{array}{r}-0.16^{*} \\
(0.05)\end{array}$ \\
\hline 6 & 2nd Generation & & & & & & - & $\begin{array}{r}-0.06 \\
(0.04)\end{array}$ & $\begin{array}{r}-0.26 * * \\
(0.04)\end{array}$ \\
\hline 7 & 3rd Generation & & & & & & & - & $\begin{array}{r}-0.20 * * \\
(0.04)\end{array}$ \\
\hline 8 & 4th Generation & & & & & & & & - \\
\hline
\end{tabular}

Note: () indicates Standard Error. $*^{*} p<.01, * p<.05$

\section{Discussion}

This study aims to examine the current state of the diversification of English version of bachelor's degrees, especially focusing the two factors: academic fields and types of universities. 723 universities' English versions of bachelor's degree were analyzed to examine three research questions. The results reveal following facts: regarding the research question 1, majority of universities express the field of discipline directly in degree-descriptions such as Bachelor of Engineering, Bachelor of literature, whereas structural description, such as Bachelor of Arts, Bachelor of Science, Bachelor of Arts in [major] or Bachelor of Science in [major], is not widely used as of 2017.

As for research question 2, when we break down the results by each academic field and type of university, different tendency can be found - especially in each academic field - professional academic fields tend to express their discipline directly, whereas transdisciplinary academic fields tend to adapt structural description. As for types of universities, National universities tend to express their discipline directly, whereas Public universities and relatively traditional private universities tend to adapt structural description. 
For research question 3, newer universities tend to have more variation of forms, compared with traditional universities.

\subsection{Characteristics of diversification of description form of English version of bachelor's degree by academic fields and types of universities}

The results show that the tendency of diversification of description form of English version of bachelor's degree differs by academic field and type of university. The finding that those factors contribute to diversification basically matches with the finding which the level of diversification of nomenclature of bachelor's degrees depending on academic fields and types of universities as found at 2004 National survey [2]. The analysis by academic fields, professional and transdisciplinary academic fields tend to express their bachelor's degree in English version in different manner. The analysis by types of universities, National university and Public and relatively traditional private universities tend to adapt structural description. If selection process of description form is similar those of nomenclature of academic fields [2], it suggests that the level of establishment of disciplines in each academic field, advantage of student recruitment, situation and the prestige of the university or past academic research achievements may have influenced the selection of description form.

The variation index by dividing the number of variations of the forms (maximum=5) that each university employs by number of degree programs was used as an indicator to measure the level of extent of the uniformity of the form of description within a university. The results clearly showed that newer universities tend to have more variation of forms, compared to traditional universities. The results may be explained that newer universities are trying to absorb alternative demands to higher education that have been emerging in newer kind of stakeholders of higher education and the general public more flexibly, compared to traditional universities and then academic fields of educational programs show more variety: Therefore conformity of description form becomes low. Apart from that, the level of establishment of disciplines of each academic field and its recognition by the general public, different targets of prospective students to recruit, situation and the prestige of the university or their research achievements may have influenced the selection of description form. One of the remaining points of discussion here is about 1st Generation Niche private universities: Though they are categorized as traditional institutions, they show relatively higher mean variation index in terms of styles of degree-description within an institution. It may be possible to explain this tendency by focusing on the variety of programs that exist in a single 1st Generation Niche private university: There can be traditional /well-established programs and new /developing kind of programs co-exist within an institution. In order to develop policies for better international recognition of qualifications, it seems to be important to concern the effect of those factors that contributes diversification of description forms of English version of bachelor's degree.

This study also shows that in whole description forms keeps extent of diversification that is consistent with results form 2015 [1] and 2004 [2] surveys. It is noted that this study is not aimed to be directly compared to the results from 2004 survey due to some different definitions of classification of forms of description [2]. As mentioned in the first section of this article, the Science Council of Japan Committee encouraged universities to employ structural description in English version of bachelor's degrees like Bachelor of Arts in [major] or Bachelor of Science in [major] as is used in U.K. and U.S. [6] in order to narrow the variation. Japanese universi- 
ties were, then, actually encouraged to shift to structural style of degree-descriptions? Based on this study, at least for the degree of the bachelor's degree, it can be said that no strong effect leading to suppression is seen. As they emphasized that it is important to have a rule about description form and disseminate it to the world. It is expected that policies for better international recognition will be developed through longitudinal national survey and analysis on whether and how the structure of diversification will change.

\subsection{Limitation and further study}

Some limitations exist in this study. First, although response rate was high (96.7\% universities in Japan), since this study analyzed number of degree programs in each university, if remaining $3.3 \%$ universities has a significantly large number of degree programs, it might affect overall trends of diversification of description form. Thus, it can be said that there is a limitation in generalizing this result. Secondly, this study only covers the data of degree programs in 2017, and it will be necessary to verify, in the longitudinal research, whether the results in this study are the same of degree programs in other years.

Another limitation can be found with the remaining policy issues that we pointed out. The Science Council of Japan Committee sought in the report of 2014 [6] encouraged to standardize description form of English version of bachelor's degree, but the essential diversification reflecting the individualization of universities was also encouraged. In this study, we applied the ratio of descriptions form and variation index as an indicator to measure the level of extent of the uniformity in the academic field, type of university and within a university.

However, even if these indicators showed that description forms of English version are not uniform, it is not possible to distinguish between unnecessary cluttering of the descriptions form or substantial diversification. There will be cases that each university decides descriptions form by referring to the precedents of other universities where there is also those by finding a high value in using the unique type of descriptions form. To investigate this issue, it is hoped that further research will be conducted to clarify the process of selection.

\section{References}

[1] N. Takahashi, and R. Mori, "The Diversification of Nomenclature of Academic Degrees in Japanese Higher Education: Current State and Transition as found by 2015 National Survey," RCUS, University of Tsukuba: University Studies, vol. 45, pp. 3-15, 2018. (in Japanese)

[2] Y. Hamanaka, "Excessive variegation of nomenclature of major disciplines in academic degrees," IDE: The Contemporary Higher Education, vol. 473, pp. 62-68, 2005. (in Japanese).

[3] R. Mori, "Excessive variegation of nomenclature of major disciplines in academic degrees -Current state of Japan and U.S.," Handout of the 1st review meeting for the role of nomenclature of major disciplines, December 2010. (in Japanese).

[4] Ministry of Education, Culture, Sports, Science and Technology, "Guidance on preparation of documents to be submitted for establishment of universities" 2019; https://www.mext.go.jp/a_menu/koutou/ninka/_icsFiles/afieldfile/2018/10/16/1410186_01. pdf (Dec. 2019, Final access). 
[5] Central Council for Education, "Reference guidelines for construction bachelor's degree programs in Japan," Report on discussions, December 2008. (in Japanese).

[6] Science Council of Japan Committee for university education's quality assurance initiatives by field, "Review for future vision on nomenclature of major disciplines in Japan," Report on discussions, September 2014. (in Japanese).

[7] Ministry of Education, Culture, Sports, Science and Technology, "School Basic Survey," Appendix of academic discipline's codes, 2017. (in Japanese).

[8] M. Kaneko, "Agents of massification of higher education," Bulletin of the National Institute of Multimedia Education, vol. 91, pp. 37-59, 1996. (in Japanese).

[9] Y. Hamanaka, "Students and education at private university found in a student survey," Handout of the 1st review meeting for private university promotion, April 2016. (in Japanese).

[10] D. Yates, D. Moore, G. McCabe, "The Practice of Statistics (1st Ed.)," New York: W.H. Freeman, 1999. 